\title{
Peranan Promosi Jabatan dan Kompensasi Terhadap Motivasi Kerja Karyawan
}

\author{
Dedy Syahyuni \\ Universitas Bina Sarana Infomatika \\ dedy.ddn@bsi.ac.id
}

\begin{abstract}
Abstrak
Motivasi kerja adalah sesuatu yang sangat diharapkan oleh perusahaan dari para karyawannya, karena dari motivasi kerja yang baik akan menimbulkan kepuasan kerja dan kinerja yang baik. Selain dari itu akan tercipta pula tingkat efektivitas kerja dan efisiensi biaya produksi. Walau demikian dalam penciptaan motivasi kerja yang baik tidaklah mudah. Banyak hal yang perlu diperhatikan dan dipersiapkan oleh manajeman sumber daya manusia perusahaan, karena begitu banyak faktor yang dapat mempengaruhinya. Dua diantaranya adalah faktor promosi jabatan dan kompensasi kerja karyawan. Dalam tulisan ini, penulis mencoba untuk melihat peranan dari promosi jabatan dan kompensai kerja karyawan terhadap terciptanya motivasi kerja karyawan. Responden yang dipakai adalah sebanyak 35 orang karyawan. Dalam tulisan ini dalam proses perhitungan menggunakan bantuan dari SPSS versi 21 dengan tingkat signifikasi $5 \%$.
\end{abstract}

Kata Kunci : Promosi, Kompensasi, Motivasi Kerja

\begin{abstract}
Work motivation is something that companies expect from their employees, because of good work motivation will lead to job satisfaction and good performance. Apart from that, the level of work effectiveness and efficiency of production costs will also be created. However, creating good work motivation is not easy. There are many things that need to be considered and prepared by the company's human resource management, because so many factors can influence it. Two of them are factors of promotion and employee compensation. In this paper, the author tries to see the role of job promotion and employee compensation for creating employee motivation. The respondents used were 35 employees. In this paper the calculation process uses the help of SPSS version 21 with a significance level of $5 \%$.
\end{abstract}

Keywords: Promotion, Compensation, Work Motivation

\section{Pendahuluan}

Motivasi kerja adalah suatu tingkat seberapa baik mental dari para karyawan dalam mengerjakan tugas perkajaan yang diamantakan kepada setiap individu. Bagaimana mereka melihat pekerjaan dan menjalankan tugas mereka. Motivasi tidak dapat dilakukan secara berkelompok karena motivasi sifatnya indidual. Oleh Karena itu tidak ada cara yang baik dalam meningkatkan individu kecuali dengan merubah pola pikir dari setiap individu dalam kelompok tersebut.

Walau dalam satu kelompok secara umum dikatakan memiliki tingkat motivasi kerja yang baik akan tetapi bila dilihat kasus per individu maka kemungkinan setiap individu memiliki tingkat motivasi yang bebeda-beda. Perbedaan ini tidak dapat di sama ratakan alasannya. Setiap orang punya mimpi atau harapan masing masing. Dari harapan ini timbulkan ekspektasi 
dan dari harapan ini timbul motivasi atas pemenuhan ekspekasti tersebut.

Banyak hal yang membuat ekspetasi dari individu terpenuhi atau tidak, bisa jadi karena beban kerja yang ada, lingkungan kerja yang memadai, pimpinan yang cukup baik dalam menjalankan tugasnya atau bisa juga karena kompensasi kerja yang adil bahkan dari sistem promosi jabatan yang dijalankan dalam perusahaan sudah berjalan secara transparan.

Menurut (Badriyah, 2017) yang dimaksud dengan promosi adalah upaya penghargaan dari perusahaan dengan cara menaikan jabatan karyawan dalam suatu organassi ataupun instansi, baik dalam organisasi pemerintah maupun organisasi nonpemerintahan (dalam hal ini swasta).

Sedangkan menurut (Siagian, 2015), Promosi jabatan adalah keadaan apabila seorang karyawan dipindahkan dari satu jenis pekerjaan kepada pekerjaan yang lain dan menggung tanggung jawab yang lebih besar dari sebelumnya, tingkatannya dalam hierarki jabatan lebih tinggi dari sebelumnya dan mendapatkan penghasilan lebih besar pula dari sebelumnya.

Sedangkan yang dimaksud dengan kompensasi yang adil adalah hal yang sangat mudah dikaitkan dengan motivasi kerja karyawan. Karena menurut beberapa penelitian terdahulu ditemukan, bahwa kompensasi memberikan dampak secara langsung dalam peningkatan motivasi kerja karyawan. Dengan kompensasi yang adil membuat para pekerja mengetahui berapa besar pekerjaan yang harus mereka lakukan untuk mendapatkan kompensasi yang mereka harapkan. Jadi bukan hanya besarnya kompensasi tetapi sistem kompensasi yang adil juga memberikan dampak bagi penciptakan motivasi kerja.

Pengertian yang dikemukakan oleh Simamora dalam (Kadarisman, 2018) menyatakan kompensasi atau Compensation adalah meliputi imbal balik finansial dan juga jasa-jasa yang berbentuk terwujud serta tunjangan-tunjangan yang diterima oleh karyawan sebagai bagian dari suatu hubungan kepegawaian dalam suatu organisasi. lebih lanjut disampaikan bahwa kompensasi adalah apa yang diterima oleh para pekerja atau karyawan sebagai wujud dari ganti sumbangan mereka kepada organisasi tempat mereka bekerja.

Pendapat yang lain dari Werther dan Davis yang dikutip oleh (Wibowo, 2017) menyatakan bahwa kompesasi sebagai apa yag diterima pekerja sebagai imbal jasa atas sumbangan para karyawan kepada perusahaan mereka.

Menurut (Hasibuan, 2016), Terdapat beberapa hal yang digolongkan sebagai tujuan pemberian kompensasi atau balas jasa dalam suatu perusahaan. beberapa diantaranya adalah kompensasi silihat sebagai ikatan kerjasama antara perusahaan dan karyawan, merupakan sarana meningkatkan kepuasan kerja karyawan, suatu cara pengadaan karyawan yang efektif, sarana peningkatan motivasi kerja karyawan, sebagai cara menstabilkan karyawan, upaya pendisiplinan karyawan, serta dapat memberikan pengaruh baik bagi serikat buruh dan juga pemerintah.

Selain dari itu, sistem promosi jabatan karyawan yang transparan juga dapat memberikan dampak pada positif bagi motivasi kerja karyawan. Karyawan dapat mengetahui alasan-alasan bagi seseorang dapat menduduki suatu jabatan bukan karena kedekatan atau pilihan atas dasar kesukaan pimpinan, tetapi seseorang menjabati posisi strategis karena memang yang besangkutan mampu dan layak dalam menjalankannya. Transparansi ini menjadi penting karena membuat karyawan dapat mementukan seberapa besar usaha yang mereka harus berikan agar harapan untuk menempati jabatan tertentu bisa tercapai. Alasan yang lain adalah adanya kepastian dari para karyawan bahwa usaha yang mereka jalankan dinilai dengan cukup adil walau pada akhirnya promosi jabatan dapat tercapai atau tidak.

Lebih lanjut menurut Greenberg dan Baron seperti yang dikutip (Wibowo, 2017), motivasi adalah merupakan suatu serangkaian proses kerja yang dapat membangkitkan (arouse), dan mengarahkan (direct), serta menjaga (maintain) dari perilaku dalam hal ini 
karyawan menuju pada pencapaian tujuan perusahaan atau organisasi.

Dalam buku Fahmi, Santoso Saroso (Fahmi, 2016), menyatakan bahwa motivasi adalah sebuah set atau kumpulan dari perilakuperilaku yang memberikan suatu landasan pikir dari seseorang karyawan untuk bertindak didalam suatu cara yang sudah diarahkan perusahaan kepadanya untuk sebuah tujuan yang secara spesifik (specific goal directed way).

Dalam hal lain menurut (Robbins, Stephen P \& Judge, 2017), pengertian motivasi diungkapkan sebagai keterkaitan antara upaya menuju setiap tujuan, kita akan mempersempit fokus menjadi suatu tujuan yang ingin dicapai terhadap sebuah perilaku yang terkait tujuan yang ingin dicapai. Sedangkan menurut Kreitner dalam (Suwatno, 2016), pengertian motivasi kerja adalah sesuatu yang disebut dengan "is Psycological prosesses that arouse dan direct goal directed behavior".

Dapat terlihat dari penjabaran sederhana diatas bahwa untuk membentuk motivasi kerja yang baik adalah sebuah keniscayaan. Perusahaan membutuhkan motivasi kerja yang baik dari karyawannya dan untuk membentuk tingkat motivasi kerja yang baik tadi harus didahului degnan perbaikan dari banyak hal dan dua diantaranya adalah promosi dan kompensasi kerja karyawan.

\section{Metode}

Penelitian ini menggunakan metode kuantitatif, dimana penelitian memfokuskan pada cara pengujian hipotesis, dengan menggunakan data yang didapatkan dengan menggunaan sebar kuisioner dan diukur secara statitik untuk mengambil kesimpulan dari fenomoena yang diangkat sebagai judul. Kuisioner yang dibuat berdasarkan tepri yang diapilih sesuai dengan variabel penelitian dan semua jawaban dari responden discoring atau dinilai dengan menggunakan skala likert.

Penelitian dilaksanakan pada unit Sumber Daya Manusia di PT Kereta Api Indonesia (Persero) Daerah Operasi 1 Jakarta yang berkantor Stasiun Cikini, Jakarta Pusat. Adapun respondennya adalah seluruh karyawan pada unit SDM sebanyak 35 orang dan penelitian ini menggunakan signifikasi $5 \%$.

Dalam penelitian ini, penulis mencoba menghitung dengan menggunakan bantuan dari apliasi SPSS versi 21. Perhitungan dilakukan dengan mengukur Validitas, Reabilitas, Uji Klasik yang terdiri dari : Uji Normalitas, Uji Multikolinier, Uji Heterokedaksitas. Lalu perhitungan juga dilanjutkan dengan menghitung atau melakukan Uji Korelasi, Uji determinasi dan $U$ ji regresi.

Menurut (Sugiyono, 2018) yang dimaksud dengan populasi adalah wilayah yang menyamaratakan obyek atau subyek penelitian juga memiliki ukuran kapasitas dan data spesifik tertentu yang sudah ditetapkan oleh peneliti sehingga dapat dipahami dan juga dapat diambil kesimpulannya.

Lebih lanjut menurut (Sugiyono, 2018) Untuk dapat mendapatkan suatu arah dan mengukur kuat lemahnya suatu hubungan diantara dua variabel atau lebih dalam sebuah peneltian maka dapat digunakan teknik atau uji korelasi.

Menurut (Priyatno, 2017) Untuk menentukan seberapa besar teliti suatu item dalam sebuah penelitian pada kuesioner, maka peneliti memerlukan suatu uji yaitu uji validitas kuesioner untuk mengukur apa yang seharusnya diukur.

Menurut (Priyatno, 2017) pengujian reliabilitas dalam sebuah peneltian sering dipakai sebagai alat tolak ukur untuk melihat semua butir pertanyaan yang dianggap valid dalam sebuah rangkaian pertanyaan kuesioner akan sifatnya konstan dari masa ke masa bila pengukuran uji ini dilalukan uji ulang kembali dimasa yang akan datang.

\section{Hasil}

Seperti yang telah dibahas pada bagian terdahuu bahwa pengujian dilakukan dalam beberapa tahapan pengujian dengan menggunakan bantuan aplikasi SPSS versi 21. Dalam penelitian ini penulis menggunakan signifikasnsi $5 \%$ jadi pada tabel $f$ didapatkan batas validitas 0.344 . Adapun hasil dari uji validitas adalah sebagai berikut : 
Tabel 1: Validitas

\begin{tabular}{|l|l|l|l|l|}
\hline Variabel & item & R Hitung & F tabel & Keterangan \\
\hline Promosi Jabatan (X1) & 1 & 0,519 & 0,344 & VALID \\
\hline & 2 & 0,683 & 0,344 & VALID \\
\hline & 3 & 0,754 & 0,344 & VALID \\
\hline & 4 & 0,470 & 0,344 & VALID \\
\hline & 5 & 0,754 & 0,344 & VALID \\
\hline & 6 & 0,692 & 0,344 & VALID \\
\hline & 7 & 0,624 & 0,344 & VALID \\
\hline & 8 & 0,565 & 0,344 & VALID \\
\hline Kompensasi (x2) & 1 & 0,578 & 0,344 & VALID \\
\hline & 2 & 0,773 & 0,344 & VALID \\
\hline & 3 & 0,614 & 0,344 & VALID \\
\hline & 4 & 0,726 & 0,344 & VALID \\
\hline & 5 & 0,715 & 0,344 & VALID \\
\hline & 6 & 0,673 & 0,344 & VALID \\
\hline & 7 & 0,729 & 0,344 & VALID \\
\hline & 8 & 0,807 & 0,344 & VALID \\
\hline & 1 & 0,662 & 0,344 & VALID \\
\hline & 2 & 0,624 & 0,344 & VALID \\
\hline & 3 & 0,607 & 0,344 & VALID \\
\hline & 4 & 0,656 & 0,344 & VALID \\
\hline & 5 & 0,687 & 0,344 & VALID \\
\hline & 6 & 0,698 & 0,344 & VALID \\
\hline & 7 & 0,582 & 0,344 & VALID \\
\hline & 8 & 0,507 & 0,344 & VALID \\
\hline & 9 & 0,658 & 0,344 & VALID \\
\hline & 10 & 0,660 & 0,344 & VALID \\
\hline & 11 & 0,650 & 0,344 & VALID \\
\hline & & & \\
\hline & & & \\
\hline & & & \\
\hline & & &
\end{tabular}

Adapun dalam uji reabilitas maka didapatkan hasil sebagai berikut:

Tabel 2: Reabilitas variabel promosi kerja

Reliability Statistics

\begin{tabular}{|l|l|}
\hline Cronbach's Alpha & N of Items \\
\hline 0.79 & 8 \\
\hline
\end{tabular}


Dari hasil perhitungan reabilitas variabel promosi didapatkan hasil yang dinyatakan reliable. Karena hasil perhitungan berada dalam rentang 0,61 - 0,80.

Tabel 3 : Reabilitas Variabel Kompensasi

Reliability Statistics

\begin{tabular}{|c|c|}
\hline Cronbach's Alpha & N of Items \\
\hline .851 & 8 \\
\hline
\end{tabular}

Dari hasil uji variabel kompensasi maka didapatkan hasil 0.851 yang artinya sangat reliable,

berikutnya adlah asil uji reabilitas variabel motivasi.

Tabel 4: Reabilitas Variabel Motivasi

\section{Reliability Statistics}

\begin{tabular}{|l|l|}
\hline Cronbach's Alpha & N of Items \\
\hline 844 & 11 \\
\hline
\end{tabular}

Untuk hasil dari uji reabilitas variabel $x$ yaitu variabel motivasi didapatkan sail 0,844 yang artinya sangat relabel. Selanjutnya dalam uji klasik yang menghitung Uji Normalitas, Uji Multikolinier, Uji Heterokedaksitas didapatkan hasil sebagai berikut:

Tabel 5 : Uji Normalitas

\section{One-Sample Kolmogorov-Smirnov Test}

\begin{tabular}{|c|c|c|}
\hline & & Unstandardized Residual \\
\hline $\mathrm{N}$ & & 35 \\
\hline & Mean & .0000000 \\
\hline TU & Std. Deviation & 2.97880700 \\
\hline & Absolute & .135 \\
\hline $\begin{array}{l}\text { Most } \\
\text { Differences }\end{array}$ & ${ }^{e}$ Positive & .135 \\
\hline & Negative & -071 \\
\hline Kolmogorov- & & 798 \\
\hline Asymp. Sig. & & .548 \\
\hline
\end{tabular}

a. Test distribution is Normal.

b. Calculated from data.

Dalam uji normalitas didapatkan hasil sebesar 0,548 yang artinya terjadi kenormalan sebaran data karena hasil Asymp berada diatas 0,5. Berikutnya adalah uji mutikolinier. 
Dari hasil uji multikolinier didapatkan bahawa tolerance sebesar 0,810 atau lebih dari 0,10 dan nilai VIF adalah 1,234 yang artinya kurang dari 10,00, jadi dapat dinyatakan bahwa dalam uji data dari ketiga variabel tidak terjadi multikolinieritas.

Uji Heterokedaksitas

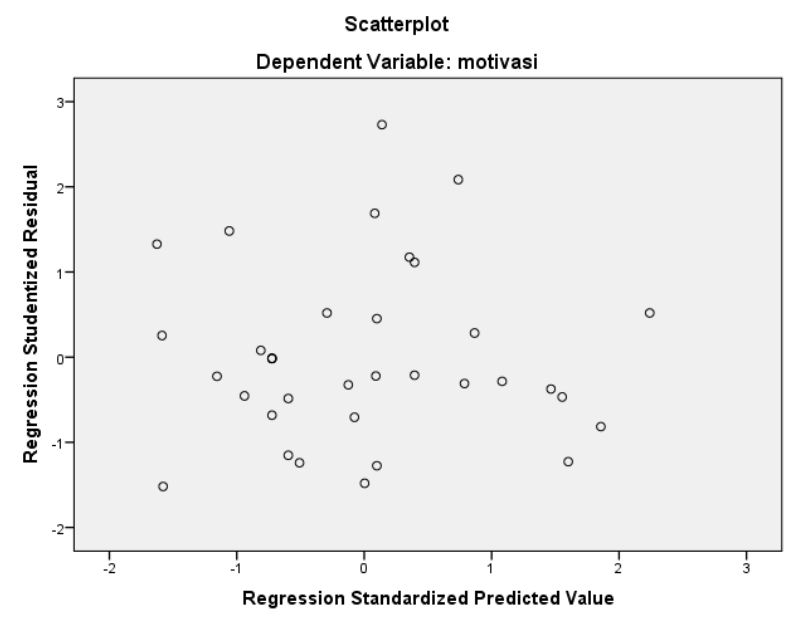

Gambar 1 : Uji Heterokedaksitas

Terlihat dalam gambar diatas bahwa titik menyebar diatas dan dibawah garis 0 , lalu tidak berkumpul pada satu tempat, lalu tidak berbentuk gelombang dan tidak berpola. Hal ini dapat disimpulkan bahwa tidak terjadi heterokedaksitas.
Selanjutnya adalah uji koreasi dan determinasi. Dalam uji korelasi dan determinasi dengan mengunakan bantuan aplikasi spss didapatan hasil sebagai berikut :

Tabel 6. Korelasi

\section{Correlations}

\begin{tabular}{|ll|l|l|l|}
\hline & & PROMOSI & KOMPENSASI & MOTIVASI \\
\hline & Pearson Correlation & 1 & $.435^{* *}$ & $.683^{* *}$ \\
& Sig. (2-tailed) & & .009 & .000 \\
& $\mathrm{~N}$ & 35 & 35 & 35 \\
& Pearson Correlation & $.435^{* *}$ & 1 & $.538^{* *}$ \\
KOMPENSASI & Sig. (2-tailed) & .009 & .001 \\
& $\mathrm{~N}$ & 35 & 35 & 35 \\
& Pearson Correlation & $.683^{* *}$ & $.538^{* *}$ & 1 \\
MOTIVASI & Sig. (2-tailed) & .000 & .001 & 35 \\
& $\mathrm{~N}$ & 35 & 35 & 35 \\
\hline
\end{tabular}

${ }^{* *}$. Correlation is significant at the 0.01 level (2-tailed). 
Tabel 7: Determinasi

\section{Model Summary}

\begin{tabular}{|l|l|l|l|l|}
\hline Model & $R$ & R Square & Adjusted R Square & Std. Error of the Estimate \\
\hline 1 & $.733^{\mathrm{a}}$ & .537 & .508 & 3.070 \\
\hline
\end{tabular}

a. Predictors: (Constant), KOMPENSASI, PROMOSI

b. Dependent Variable: MOTIVASI

Dari hasil diatas didapatkan hasil sebesar 0,733 dalam perhitungan korelasi dari kedua variabel bebas terhadap variabel tetap, jadi dapat dikatakan secara bersama variabel kompensasi dan promosi berhubungan kuat dengan variabel motivasi. Berdasarkan tabel interpretasi didapatkan bahwa 0,733 berada dalam rentang 0,60 sampai 0,799 berada dalam kategori hubungan kuat.

Selain hasil diatas didapatkan hasil determinasi atau $r$ sebesar 0.733 , hasil lain juga

Tabel 7 ANOVA ${ }^{a}$

\begin{tabular}{|l|l|l|l|l|l|}
\hline Model & Sum of Squares & df & Mean Square & $F$ & Sig. \\
\hline \multicolumn{1}{|l|}{$\begin{array}{l}\text { Regression } \\
1\end{array} \begin{array}{l}\text { Residual } \\
\text { Total }\end{array}$} & 350.48 & 2 & 175.24 & 18.587 & $.000^{\mathrm{b}}$ \\
\hline
\end{tabular}

a. Dependent Variable: MOTIVASI

b. Predictors: (Constant), KOMPENSASI, PROMOSI

Dari hasil uji anova didapatkan hasil yang baik dimana angka Sig yang didapatkan sebebar 0.000 yang artinya model valid hal ini terlihat dari hasil yang $<0,05$. didapatkan yaitu hasil uji determinasi sebesar 0,537. Dari hasi ini dapat dikatakan bahwa ada hubungan (korelasi) yang kuat diantara ketiga variabel, yaitu kompensasi, promosi dan motivasi kerja. Sedangkan dalam uji determinasi degan abantuan SPSS didapatkan hasil sebesar 0,537 yang artinya variabel kompensasi dan promosi jabatan memberikan kontribusi terjadinya variabel motivasi sebesar $53,7 \%$ dan selebihnya atau 46,35 dipengaruhi oleh variabel lain yang tidak di bahas pada penelitian ini. 


\section{Coefficients $^{a}$}

\begin{tabular}{|l|l|l|l|l|l|l|}
\hline \multirow{2}{*}{ Model } & \multicolumn{2}{|l|}{ Unstandardized Coefficients } & Standardized Coefficients & & Sig. \\
\cline { 2 - 5 } & $B$ & Std. Error & Beta & & \\
\hline (Constant) & 9.439 & 6.296 & & 1.499 & 144 \\
1 PROMOSI & .693 & .167 & .554 & 4.146 & .000 \\
KOMPENSASI & .410 & .185 & .296 & 2.219 & .034 \\
\hline
\end{tabular}

a. Dependent Variable: MOTIVASI

Dari hasil diatas maka didapatkan persamaan sebagai berikut : $Y=9.439+0,693 \times 1$ $+0,410 \times 2$. Jadi bila variabel lain bernilai konstan maka nilai $Y$ adalah 9,439 . Apabila variabel lain tetap atau konstan dan variabel $\mathrm{X} 1$ berubah satu satuan maka $Y$ berubah sebesar 0,693 dan apabila variabel $\mathrm{X} 2$ berubah 1 satuan dan variabel lain tetap maka $Y$ akan berubah 0,410 .

Berdasarkan hasil uji korelasi diatas maka didapatkan adanya hubungan yang kuat diantara variabel promosi dengan variabel motivasi dengan nilai 0,683 . Dalam perhitungan hubungan diantara variabel kompensasi dengan motivasi didapatkan hasil sebesar 0,538 diman dikategorikan dengan hubungan yang kuat.

Dari beberapa penelitian sebelumnya memang ditemukan adanya hubungan dan pengaruh yang cukup baik diantara variabal tersebut baik secara bersama sama atau sendiri sendiri. Seperti pada hasil penelitian dari Husna. Menurut (Husna, 2018), dapat disimpulkan bahwa semakin tinggi tingkat motivasi kerja yang diberikan karyawan maka semakin tinggi pula kinerja guru (contoh kasus SMAN 1 Canduang, Kabupaten Agam). Dimana pada penelitan yang lain motivasi adalah salah satu faktor atau variabel utama dalam peningkatan kinerja karyawan.

Selain dari itu, dalam penelitian yang lain disebutkan, menurut (Haniyah, 2019) promosi jabatan memberikan pengaruh yang cukup signifikan terhadap motivasi kerja karyawan dengan angka skor 56,1\%. Sedangkan menurut penelitian (Mubaroq, 2017), didapatkan, berdasarkan hasil penelitian terdapat pengaruh kompensasi terhadap motivasi kerja adalah sebesar 70,06\% .

Sedangkan dari hasil penelitian yang lain didapatkan hasil yang hampir sama, menurut (Witarman, 2017) dari hasil penelitian beliau didapatkan hasil bahwa promosi jabatan secara signifikan memberikan dampak sebesar 26,7\% terhadap peningkatan motivasi kerja, Sedangkan kompensasi memberikan pengaruh sebesar $16,4 \%$ terhadap peningkatan motivasi kerja.

Jadi dari beberapa hasil penelitian diatas dapat dilihat bahwa walau hasilnya berbeda beda akan tetapi dalam kedua penelitian tersebut kedua variabel memiliki pengaruh yang cukup besar terhadap terbentuknya variabel motivasi kerja.

\section{Kesimpulan dan Saran}

Kesimpulan yang bisa disampaikan atas tulisan ini adalah :

1. Setiap perusahaan membutuhkan tingkat motivasi kerja yang baik dari para karyawannya karena dari motivasi kerja yang baik dapat menimbulakan efisiensi dan efektivitas kerja bagi perusahaaan.

2. Banyak hal atau variabel yang membuat terbentuknya motivasi atau perbaikan tingkat motivasi kerja karyawan, dua diantaranya adalah promosi jabatan dan kompensasi kerja karyawan.

3. Dari hasil tulisan ini didapatkan bahwa variabel promosi jabatan dan 
kompensasi memiliki hubungan positif atas terbentuknya motivasi kerja, hal ini terlihat dari hasil uji SPSS yang menunjukan angka 0,733 dan hal in dinyakatan bahawa hubunganya kuat

4. Selain itu dilihat dari hasil uji yang menggunakan bantuan aplikasi SPSS didapatkan bahwa variabel promosi dan kompensasi memberikan konribusi atas terbentuknya vaiabel motivasi kerja sebesar 53 persen dan selebihnya (47 persen) dipengaruhi oleh lain yang tidak dibahas dalam tulisan ini.

Adapun saran yang bisa disampaikan adalah :

1. Perlu adanya upaya peningkatan motivasi dari perusahaan sehingga tercipta kinerja yang maksimal dari karyawan

2. Perlu adanya pembahsan lebih lanjut mengenai apa saja yang dapat meningkatkan motivasi bagi karyawan.

3. Menginat dalam kasus ini adanya hubungan yang kuat antara promosi jabatan dan kompensasi atas terbentuknya motivasi kerja maka perlu adanya upaya mempertahankan kondisi tersebut.

\section{Daftar Pustaka}

1. Badriyah, M. (2017). Manajemen Sumber Daya Manusia. Bandung: Pustaka Setia.

2. Fahmi, I. (2016). Perilaku Organisasi. Bandung: Alfabeta.

3. Haniyah, R. A. (2019). PENGARUH PROMOSI JABATAN TERHADAP MOTIVASI KERJA KARYAWAN PADA PLASA TELKOM LEMBONG BANDUNG. Almana, 3(3). Retrieved from http://journalfeb.unla.ac.id/index.php/ almana/article/view/1260/784

4. Hasibuan, M. (2016). Manajemen Sumber Daya Manusia. Jakarta: Bumi Aksara.

5. Husna, N. (2018). PENGARUH MOTIVASI KERJA TERHADAP KINERJA GURU PADA SMAN 1 CANDUANG KABUPATEN AGAM. Ekobistek, 7(2). Retrieved from http://lppm.upiyptk.ac.id/ojsupi/index.
php/EKOBISTEK/article/view/61/35

6. Kadarisman. (2018). Manajemen Kompensasi. Jakarta: Raja Grafindo Persada.

7. Mubaroq, rifqi A. \& W. Z. (2017). PENGARUH KOMPENSASI TERHADAP MOTIVASI KERJA KARYAWAN PADA SHADIQ SHARIA EX. BPRS CIPAGANTI BANDUNG. Manajemen Ekonomi Dan Akutansi, 1(3). Retrieved from http://journal.stiemb.ac.id/index.php/ mea/article/view/87/94

8. Priyatno, D. (2017). Panduan Praktis Olah Data Menggunakan SPSS.

Yogyakarta: Andi Offset.

9. Robbins, Stephen P \& Judge, T. A. (2017). Perilaku Organisasi (16th ed.). jakarta: Salemba Empat.

10. Siagian, S. P. (2015). Manajemen Sumber Daya Manusia. Jakarta: Bumi AKsara.

11. Sugiyono. (2018). Metode Penelitian Kuantitatif. (Setiyawami, Ed.) (Cetakan ke). Bandung: Alfabeta.

12. Suwatno. (2016). Manajemen Sumber Daya Manusia. Bandung: Alfabeta.

13. Wibowo. (2017). Manajemen Kinerja (kelima). Jakarta: Raja Grafindo Persada

14. Witarman. (2017). PENGARUH PROMOSI JABATAN DAN KOMPENSASI TERHADAP MOTIVASI SERTA IMPLIKASINYA TERHADAP PRODUKTIVITAS KERJA KARYAWAN PADA PERUSAHAAN MANUFAKTUR DI CIKARANG. Manajemen Dan Bisnis Kreatif, 3(1). Retrieved from journal.ubpkarawang.ac.id/index.php/ Manajemen/article/view/239 